\section{ETHNOLOGY AND SPIRITUALISM}

$7 \mathrm{HE}$ Academy of February $\mathbf{I} 5$ contains a review by Mr. A. R. Wallace, of my "Primitive Culture," where he raises a point on which I wish to make some further observations; but inasmuch as the form of publication of that journal adapts it rather to criticism than to correspondence, I ask leave to change the venue, and make my remarks in the columns of NATURE.

In "Primitive Culture" (Vol. i., pp. 279-84), I have given an account of the widespread popular belief in "were-wolves," including under this heading the analogous belief in man-hyænas, man-tigers, \&c. According to this superstition, certain human beings are considered to be temporarily transformed into wolves, hyænas, or tigers, and in these shapes to go about preying on mankind. While expressing an opinion that "the origin of this idea is by no means sufficiently explained," I have offered two suggestions as bearing on its prevalence in the world: first, that such notions are consistent with the familiar doctrines of the lower culture as to transmigration of souls and transformation of bodies; second, that certain insane persons do actually suffer under the delusion that this transformation (the idea of which popular belief has put into their minds) has really happened to themselves, and they prowl about like wild beasts accordingly. Mr. Wallace disapproves of this treatment of the subject, and propounds a view of his own, as follows : "A recognition of the now well-established phenomena of mesmerism would have enabled Mr. Tylor to give a far more rational explanation of were-wolves and analogous beliefs than he offers us. Were-wolves were probably men who had exceptional power of acting upon certain sensitive individuals, and could make them, when so acted upon, believe they saw what the mesmeriser pleased; and who used this power for bad purposes. This will explain most of the alleged facts, without resorting to the short and easy method of rejecting them as the results of mere morbid imagination and gross credulity."

Let me now first observe that Mr. Wallace's explanation does not supersede my suggestions; indeed, he meets neither of the points which I endeavour, however tentatively, to deal with. He offers nothing like a reason why knavish sorcerers in districts of Europe, Asia, Africa, and America should have all hit upon the device of imposing the same peculiar delusion upon their dupes; nor does he account for the fact, vouched for by satisfactory evidence, that in certain cases the supposed were-wolf is himself utterly persuaded of the reality of his own transformation, and goes to execution believing in his offence. The proofs are, I think, convincing, here as elsewhere in the history of magic, that sorcerers were originally and still are usually more or less believers in their own magical pretensions - though very many used and use fraudulent means to enhance their supposed powers; and some, who may be reckoned among the vilest of the human race, are simply professional impostors. Yet Mr. Wallace's suggestion, though it does not do away with the need of mine, seems to me valuable as a well-directed attempt to explain a part of the matter left untouched by me. His theory that a were-wolf may be a person possessed of the peculiar faculty exerted by mesmerists, of making others delusively imagine that they see and hear what in fact does not happen, is a theory at any rate plausible, and possibly on the track of explaining much of the power belonging to sorcerers, savage and other. (I may remark incidentally that the power of mesmerists in producing anzesthesia and working on the imagination of their patients has never been contradicted by me.) Now, without committing myself to Mr. Wallace's idea, beyond saying that it is plausible and worth pursuing, I proceed to apply it somewhat tarther. Granting that a were-wolf, in virtue of being a person capable of exerting mesmeric influence, can delude people, and even assemblies of people, into fancying that they perceive monstrous unrealities, the question arises, Was any one with this were-wolf-faculty present in the room when Mrs. Guppy made her celebrated aërostatic entrance? Is Mr. D. D. Home a werewolf? Is a professional "medium" usually or ever a person who has the power of acting on the minds of sensitive spectators, so as to malke them believe they see what he pleases? Pursuing this subject yet a step farther, I have now to call Mr. Wallace's attention to an interesting fact. The sorcerers of the Abipones of South America, who by mere roaring within their tents threw the credulous savages into agonies of panic terror, caused by vivid belief that tigerspots were in the act of coming on their (the sorcerers') bodies, that their nails were growing into claws, that they were actually transforming themselves into tigers, deadly though invisible--these sorcerers were actually the professional spiritualistic mediums of the tribe, part of whose business it was to hold intercourse with the spirits of the dead, causing them to appear visibly, or carrying on audible dialogues with them behind a curtain. - Mr. Wallace, as the most eminent scientific man who has taken up what are known as modern "spiritualistic doctrines," no doubt has the ear of all who hold these doctrines. I think it may bring about investigations leading to valuable results if $\mathrm{Mr}$. Wallace will inform spiritualists with the weight of his authority that he believes in the existence of a class of men who, in his words, have exceptional power of acting upon certain sensitive individuals, and can make them, when so acted upon, believe they see what the mesmeriser pleases, and who use this power for bad purposes.

With reference to other parts of Mr. Wallace's review of my work, I have to thank him for several valuable comments, while, at the same time, I venture to express an opinion that some of his objections to my ethnological treatment of spiritualism are unreasonable, and especially I wonder that so serious a student of natural science should make it a ground of complaint against me that in treating of difficult and important problems I consider it necessary to bring forward copious and widely distributed evidence. But rejoinders to reviews are seldom desirable in themselves, and my justification for the present note lies in the importance of drawing attention to a matter worth considering by persons on both sides of the spiritualistic controversy. $\quad$ E. B. TyLoR

\section{DREDGING EXPEDITIONS}

THE occasion of an American Dredging Expedition recently starting, leads us to make the following remarks on such Expeditions in general, more especially upon one whose programme has lately come to our ears.

England has perhaps of all countries done the most for dredging. We have only to point to such names as Forbes, Ball, McAndrew, Wallich, Jeffreys, Wyville Thomson, and Carpenter, as among the landmarks in the cause. Indeed, for many years coast dredging has been a popular amusement with the marine naturalist and collector, and many a prize has been in this manner turned up.

In I868 Messrs. Carpenter, Thomson, and Jeffreys were fortunate enough to obtain the use, free of expense, of a Government steamer, and, armed with a substantial grant from the Royal Society, tried their luck in the deep sea. The following year the Government again gave them the use of a vessel, and the Royal Society a further grant of 200l. Again in I870 they went out at the country's expense. The great and important results obtained during these cruises are pretty well known to the scientific world, and it is unnecessary to repeat them here.

In the year last mentioned an unheard-of circumstance took place. An English yachtsman, Mr. Marshall 